NBER WORKING PAPER SERIES

AN EMPIRICAL ANALYSIS OF THE FED'S TERM AUCTION FACILITY

Efraim Benmelech

Working Paper 18304

http://www.nber.org/papers/w18304

\author{
NATIONAL BUREAU OF ECONOMIC RESEARCH \\ 1050 Massachusetts Avenue \\ Cambridge, MA 02138 \\ August 2012
}

I thank Ian Dew-Becker, Charlie Calomiris, Simon Gilchrist, James Hamilton, Laura Jones Dooley, Ross Levine, Jeff Miron, and seminar participants at the Cato Papers on Public Policy Conference for useful comments. I acknowledge financial support from the Cato Institute. All errors are my own. The views expressed herein are those of the author and do not necessarily reflect the views of the National Bureau of Economic Research.

NBER working papers are circulated for discussion and comment purposes. They have not been peerreviewed or been subject to the review by the NBER Board of Directors that accompanies official NBER publications.

(C) 2012 by Efraim Benmelech. All rights reserved. Short sections of text, not to exceed two paragraphs, may be quoted without explicit permission provided that full credit, including $\odot$ notice, is given to the source. 
An Empirical Analysis of the Fed's Term Auction Facility

Efraim Benmelech

NBER Working Paper No. 18304

August 2012

JEL No. E44,E52,E58,G01,G21,G28

\begin{abstract}
$\underline{\text { ABSTRACT }}$
The U.S. Federal Reserve used the Term Auction Facility (TAF) to provide term funding to eligible depository institutions from December 2007 to March 2010. According to the Fed, the purpose of TAF was to inject term funds through a broader range of counterparties and against a broader range of collateral than open market operations. The overall goal of the TAF was to ensure that liquidity provisions could be disseminated efficiently even when the unsecured interbank markets were under stress. In this paper I use the TAF micro-level loan data and find that about 60 percent of TAF loans went to foreign banks that pledged asset-backed securities as collateral for these loans. The data and analysis illustrate the major role that foreign - in particular, European - banks currently play in the U.S. financial system and the resultant currency mismatch in their balance sheets. The data suggest that foreign banks had to borrow from the Federal Reserve Bank to meet their dollar-denominated liabilities.
\end{abstract}

\author{
Efraim Benmelech \\ Kellogg School of Management \\ Northwestern University \\ 2001 Sheridan Road \\ Evanston, IL 60208 \\ and NBER \\ e-benmelech@kellogg.northwestern.edu
}




\title{
An Empirical Analysis of the Fed's Term Auction Facility
}

\begin{abstract}
The U.S. Federal Reserve used the Term Auction Facility (TAF) to provide term funding to eligible depository institutions from December 2007 to March 2010. According to the Fed, the purpose of TAF was to inject term funds through a broader range of counterparties and against a broader range of collateral than open market operations. The overall goal of the TAF was to ensure that liquidity provisions could be disseminated efficiently even when the unsecured interbank markets were under stress. In this paper I use the TAF micro-level loan data and find that about 60 percent of TAF loans went to foreign banks that pledged asset-backed securities as collateral for these loans. The data and analysis illustrate the major role that foreign - in particular, European - banks currently play in the U.S. financial system and the resultant currency mismatch in their balance sheets. The data suggest that foreign banks had to borrow from the Federal Reserve Bank to meet their dollar-denominated liabilities.
\end{abstract}

\section{INTRODUCTION}

The Term Auction Facility (TAF) program was one of the main tools used by the Federal Reserve and the U.S. fiscal authorities during the financial crisis. The goal of this program - as described by the Federal Reserve Bank - was to intervene in the interbank money markets because of the difficulties experienced by banks in the United States and Europe. Initially, the Federal Reserve Bank used open market operations to maintain the effective federal funds rate near its target rate and enacted several measures to encourage borrowing at the discount window. ${ }^{1}$ However, these moves failed to stimulate the market as the Fed has expected. On December 12, 2007, therefore, the Federal Reserve Bank introduced the Term Auction Facility. The TAF provided longer-term financing to eligible depository institutions through auctions at predetermined dates. At its peak, the TAF amounted to more than $\$ 500$ billion and was the largest expansion on the Federal Reserve

\footnotetext{
${ }^{1}$ To encourage banks to borrow at the discount window, the Federal Reserve Bank reduced the discount window penalty rate from 100 basis points to 50 basis points on August 17, 2007, and extended the term of financing from overnight to as long as thirty days.
} 
Bank's balance sheet. Lending through the TAF gradually faded away, and the final TAF auction was conducted on March 8, 2010.

One of the reasons for the introduction of TAF during the early stages of the financial crisis was to provide banks with Federal Reserve liquidity without forcing them to face the stigma of borrowing from the discount window. Indeed, according to the chairman of the Federal Reserve Bank, the associated stigma made banks reluctant to use the discount window:

In August 2007,..., banks were reluctant to rely on discount window credit to address their funding needs. The banks' concern was that their recourse to the discount window, if it became known, might lead market participants to infer weakness - the so-called stigma problem.

Speech at the Federal Reserve Board Conference on Key Developments in Monetary Policy, Washington, D.C., by Chairman Ben Bernanke (Bernanke (2009))

However, even borrowing from the TAF had a stigma attached to it, and as a result, data on the loans that were made in TAF, as well as identity of the banks that participated in the auctions, were not disclosed initially. Later, the Federal Reserve Bank disclosed data on the loans made under the TAF, as well as information on the other credit and liquidity programs it used during the crisis.

While the effectiveness of TAF in reducing rates in the interbank market has been debated by both academic economists and policy makers (see e.g., McAndrews, Sarkar and Wang 2008 and Taylor and Williams 2009), little is known about the identity of the banks that participated in the auctions, the nature of the collateral used, and the terms on the individual loans. This paper fills the gap by using the micro-level loan dataset released by the Federal Reserve. The TAF data, which contain detailed information on the loans and the participating financial institutions, provide a rare glimpse into the injection of emergency liquidity by the Federal Reserve Bank, as well as the identity of the banks obtaining credit and in particular the type of assets they pledged as collateral.

I find that foreign banks accounted for 58 percent of TAF lending, with a total amount of $\$ 2.2$ trillion, compared to $\$ 1.6$ trillion for U.S. banks. During the auction of December 2007 and through most of 2008, foreign banks accounted for the vast majority of the lending, with amounts that ranged between twofold and fourfold the total lending to U.S banks. U.K.-based Barclays was the largest borrower in the TAF, followed by Bank of America, Royal Bank of Scotland, Wells 
Fargo, and Wachovia. Out of the ten largest borrowers, five are foreign banks, and out of the fifty largest borrowers, more than thirty are from foreign countries.

Next, I compare the collateral structure of domestic and foreign banks. I find that most of the banks and financial institutions that pledged asset-backed securities (ABS) as collateral were foreign - primarily European - banks. For example, the bank that pledged the largest amount of ABS for a given loan is Société Générale (France), followed by Norinchukin Bank (Japan), Dexia (Belgium), Barclays (U.K.), and UBS (Switzerland). Among the ten banks that pledged the largest amounts of collateral there are only two American banks (State Street and U.S. Central Federal Credit Union). Why did the Federal Reserve allocate the majority of TAF loans to foreign bank? Why were foreign banks more likely to pledge the riskier asset-backed securities and collateralized debt obligations (CDO) as collateral?

One potential explanation is that the meltdown of the structured finance market and the severe deterioration in the credit ratings of ABS necessitated liquidity injections to institutions that suffered major loses due to their exposure to the structured finance market. However, U.S. banks that borrowed from the TAF and had large exposures to ABS, such as Citibank and Bank of America, did not pledge asset-backed securities at the same level as European banks. Thus, while some of the Federal Reserve lending was probably aimed at injecting liquidity to financial institutions that held securities that were illiquid at the time, this is unlikely to be the only reason for the dominance of European banks in TAF.

Another explanation for the large number of loans made to foreign banks is that these banks suffered from a currency mismatch in their balance sheets. Many foreign banks were active players in the creation and issuance of structured finance products. As money markets ground to a halt, these banks required financing to meet the needs of rolling over their short-term liabilities. Furthermore, foreign banks were also subject to a currency mismatch in managing their assets and liabilities. While the main source of funding for some of these banks was based on demand deposits and other forms of credit in their home countries that were denominated in their home currencies - mostly the British pound and euro - many European banks issued liabilities in U.S. money markets that were denominated in the U.S. dollar. Thus, not only were foreign banks subject to a roll-over risk, but they also suffered from a currency mismatch and had to rely on special facilities such as the currency swap lines between central banks including the European Central Bank, Bank of England, and Swiss National Bank, and Federal Reserve Bank, as well as on special lending programs such 
as the TAF. European banks were more likely to bid for TAF money because they were more severely affected by the financial crisis, given their exposure to currency mismatch between assets and liabilities.

The rest of the paper is organized as follows. Section 2 provides the institutional details of the Term Auction Facility. Section 3 describes the dataset and provides summary statistics on the evolution of the TAF over time. Section 4 displays the empirical analysis. Section 5 discusses the Federal Reserve Bank's lending to foreign banks. Section 6 concludes.

\section{The Term Auction Facility}

Global money markets suffered serious disruptions in the summer of 2007 when the rates of interbank term loans rose to unusually high levels. ${ }^{2}$ The TED spread - the difference between the three-month London inter-bank offered rate (LIBOR) and the three-month U.S. Treasury bill rose from its typical level of 30 basis points to about 50 basis points and then to 200 basis points by the summer of 2007. This widening was a reason for major concern because the TED spread is an indicator of perceived credit risk in the general economy. Moreover, according to a New York Federal Reserve Bank research paper:

[T]he volume of transactions in the inter-bank market declined, and borrowers reportedly often could not obtain funds at the posted rates. Since the LIBOR affects interest rates on a wide variety of loans and securities (e.g. home mortgages and corporate loans), unusually high term rates can have disruptive effects on the economy. (McAndrews, Sarkar and Wang 2008, 1)

The Federal Reserve Bank responded to the disruptions in the money markets with the traditional tools of monetary policy - namely, open market operations to maintain the effective federal funds rate near its target rate. However, despite the Federal Reserve Bank's efforts in the overnight funding market, the rates on term loans in the interbank market kept rising. In an attempt to ease the strains in the money markets, the Federal Reserve Bank resorted to non traditional tools of monetary policy. Perhaps the most important tool used for this purpose was the Term Auction Facility.

\footnotetext{
${ }^{2}$ Term funding is typically made with maturity terms of one-month or longer.
} 
The TAF was introduced on December 2007 in the early stages of the financial crisis to provide Federal Reserve liquidity funding by auctioning off short-term funding, without forcing banks to face the stigma of borrowing from the Federal Reserve's discount window. Under the TAF, the Federal Reserve auctioned term funds to depository institutions. All depository institutions that were eligible to borrow under the primary credit program of the Federal Reserve Bank were eligible to participate in TAF auctions. All loans extended under the TAF were fully collateralized, and the funds were allocated through an auction, in which participating depository institutions placed bids specifying an amount of funds, up to a pre-specified limit, and an interest rate that they would be willing to pay for such funds. The funds were allocated beginning with the highest interest rate offered until either all funds were allocated or all bids were satisfied. All borrowing institutions paid the same interest rate, either the rate associated with the bid that would fully subscribe the auction or, in the case that total bids were less than the amount of funds offered, the lowest rate that was bid. The TAF was created under the Federal Reserves standard discount window lending authority granted under Section 10B of the Federal Reserve Act. The auctions were administered by the Federal Reserve Bank of New York, with loans granted through the twelve Federal Reserve Banks.

TAF funding supplemented the U.S. dollar funding received by global banks around the world under the central bank swap facilities between the Federal Reserve Banks and the Banco Central do Brasil, Bank of Canada, Danmark's Nationalbank, Bank of England, European Central Bank, Bank of Japan, Bank of Korea, Banco de Mexico, Reserve Bank of New Zealand, Norges Bank, Monetary Authority of Singapore, Sveriges Riksbank, and Swiss National Bank.

From the first facility on December 17, 2007, to the final TAF auction on March 8, 2010, the Federal Reserve Bank conducted sixty auctions. The amount of term loans auctioned was initially between $\$ 20$ and $\$ 30$ billion but was later increased to $\$ 50$ billion and $\$ 75$ billion. The facility size increased to $\$ 150$ billion in October 2008 and remained at that level until June 2009. During the second half of 2009 and the first three months of 2010, the amount auctioned gradually declined, and by the final auction in March 2010, only $\$ 3.4$ billion was loaned out.

Whether TAF was effective in reducing rates in the interbank market has been debated by both academic economists and policy makers. A working paper of the Federal Reserve Bank of New York (McAndrews, Sarkar, and Wang 2008) provides empirical evidence that TAF has helped to ease strains in the interbank market. In contrast, according to Taylor and Williams (2009,) TAF 
had no impact on interest rate spreads. According to McAndrews, Sarkar, and Wang (2008), the major problem in the money markets in 2007-2008 was lack of liquidity, and hence the TAF was effective because it provided central bank liquidity to the banking system when the interbanking system collapsed. In contrast, Taylor and Williams (2009) argue that the main problem in the market was not liquidity but rather counter-party risk, which TAF funding could not have solved.

\section{Data And Summary Statistics}

The data analyzed here come from the Federal Reserve Bank disclosure of each of the individual term loans provided under the TAF. ${ }^{3}$ The dataset lists 4,214 individual loans spanning the auctions from December 12, 2007, until the last auction on March 8, 2010.

The dataset includes micro-level detailed information for each loan contract on the contract terms, the borrower's identity, and the broad categories of the securities against which the loans were made. The loan contract terms include the interest rate on the loan (in percent), the loan maturity (in days), and the loan amount (in million of dollars). The dataset also provides information of the borrower that includes the borrower's name, city, and state. ${ }^{4}$ In addition, the Federal Reserve Bank discloses information on the underlying collateral against which the loan was granted. In particular, it reports the amount of unencumbered collateral (defined as the lendable value of the borrower's collateral), as well as the broad categories of the assets used as collateral. There are twelve asset type categories in the data: commercial loans, residential mortgages, commercial real estate loans, consumer loans, U.S. Treasury/Agency securities, municipal securities, corporate securities, MBS and CMO issued by government-sponsored enterprises, mortgage-backed securities (MBS) and collateralized mortgage obligations (CMO )issued by private corporations, asset-backed securities, international securities, and other collateral. Finally, the dataset breaks down the dollar value of collateral by broad credit rating categories.

\subsection{Loan Characteristics}

Table 1 displays descriptive statistics for the main loan characteristics. As Panel A shows, the average loan amount (in millions) is $\$ 906.1$ million and the median is $\$ 125.0$ million. The dispersion in loan amount ranges widely, from a minimum of $\$ 1.4$ million (First Merchant Bank of Indiana)

\footnotetext{
${ }^{3}$ The data can be downloaded at http:www.federalreserve.govnewseventsreform_taf.htm\#datadesc .

${ }^{4}$ For foreign borrowers the dataset lists the city and state of their U.S. branch, which is in most cases New York City.
} 
to the largest loans of $\$ 15,000$ million (to Bank of America, Barclays, Citibank, JP Morgan Chase, Wachovia, and Wells Fargo). The average loan term is 45.6 days and ranges from 13 days to 85 days. The average annualized interest rate is 0.900 percent and ranges from 0.200 percent to 4.670 percent. As explained in Section 2, the TAF was conducted through auctions in which all successful bids were subject to the same interest rate and loan terms. Thus, although loan amounts vary across banks and over time, all banks borrowing in the same auction obtained loans with the same interest rates and loan maturities.

In addition to the loan amount there is strong heterogeneity in the amounts and types of collateral posted by the borrowing banks. Borrowers pledged unencumbered collateral with an average value of $\$ 4,285.4$ million. The median collateral value is $\$ 571.0$ million and the range is from $\$ 5.1$ million (Timberwood Bank) to $\$ 185,410.0$ million (Bank of America). I also calculate the ratio of the face amount of the loan to the value of the unencumbered collateral and report it in the last row of Table 1. As the table shows, the average loan-to-collateral ratio is 0.334 and the median is 0.286. Loan-to-collateral rates increased after the peak of the crisis as collateral values increased and haircuts on collateral declined. For example, the average loan-to-value in 2008 was 0.255 compared to 0.370 and 0.460 in 2009 and 2010, respectively. Although the loan-to-collateral ratios appear to be low and conservative, it is not clear whether these numbers are based on market values or on face values of the underlying collateral.

\subsection{The Collateral Structure of TAF Loans}

I now analyze the composition of collateral in TAF loans. Given that loan terms as well as loan rates were determined at the auction level, the only sources of inter-bank variation were the amount of the loan and the amount and type of the collateral. Indeed, banks pledged different types of assets as collateral for their loans, and most TAF loans were secured by numerous securities from different asset types. Table 2 provides a detailed analysis of collateral structure for the 4,214 TAF loans. The table reports summary statistics for the dollar amount (in millions) as well as the number of loans for which collateral was pledged in each asset category.

The largest collateral category (based on the dollar amount of the assets pledged) is residential mortgages. The mean amount of residential mortgages used as collateral is $\$ 3,786.3$, and it was used as collateral in 465 individual loans. The next largest category is asset-backed securities, which according to the Federal Reserve definitions include securities collateralized by assets other than 
first-lien mortgages, including collateralized debt obligations (CDOs). More than 1,301 loans were backed by ABS and the mean collateral pledged in this category is $\$ 2,562.8$ million and ranges from $\$ 0.4$ million to $\$ 25,953.7$ million.

The most popular asset class based on the number of loans that used it as collateral is commercial loans, which were used in 2,291 loans, followed by commercial real estate and corporate securities, which were used in 1,624, and 1,507 loans, respectively. Finally, U.S Treasury/Agency securities were used in 833 loans with a mean collateral value of $\$ 348.8$ millions.

The dataset also breaks down the collateral pool by credit rating categories. ${ }^{5}$ Table 3 reports summary statistics for the collateral assets by the major credit rating classifications. AAA-rated U.S Treasury/Agency securities (including agency MBS and CMO) amounted, on average, to $\$ 650.3$ million. The amount of other AAA-rated securities pledged as collateral was on average $\$ 1,845.8$ per loan, and these were used in 1,859 loans. AA-rated and A-rated securities were used in 1,681, and 1,817 loans, respectively, and accounted for about $\$ 380$ million each of the collateral pool. Other rating categories include BBB-rated (mean $\$ 238.0$ million) and "other investment grade" securities (mean $\$ 1,232.6$ ).

\section{EMPIRICAL ANALYSIS}

\subsection{Determinants of Loan Characteristics}

I begin the empirical analysis of TAF loans by analyzing the characteristics of the loans. The eight OLS regressions reported in Table 4 use different specifications to predict the determinants of the loan terms. For each of the four loan determinants I report results from regressions that do not include bank fixed-effects (between analysis) and regressions that utilizes variation over time using bank fixed-effects (within analysis). As explanatory variables I use collateral dummy variables that take the value of one if a particular asset is included in the collateral pool and zero otherwise. All regressions include year $\times$ month fixed-effects to account for time-varying effects. ${ }^{6}$

The table reports results for the following loan characteristics:loan amount (in logs), interest rate, loan term, and loan-to-collateral ratio. However, it should be noted that because TAF loans were granted at auction, the same interest rate and loan term applied to all banks participating in

\footnotetext{
${ }^{5}$ The dataset reports asset types and credit ratings separately and hence does not enable classification that is based on both credit ratings and asset class.

${ }^{6}$ Although I use collateral dummy variables, the analysis yields similar results when using the actual share of collateral in each asset category.
} 
each auction. In contrast, the loan amount, the ratio of loan to collateral (the inverse of the loan "haircut"), and the nature of the assets pledged as collateral varied across banks within an auction. As Table 4 shows, the composition of the collateral has little explanatory power in bearing on loan outcomes. First, few if any of the explanatory variables turn out to be significant in regressions that use the interest rate or loan term as dependent variables. Second, the R-squared in the regressions shows that the addition of bank fixed-effects does not change the adjusted R-squared in the interest rate and loan term regressions, indicating that bank-specific effects had no impact on the loan rate and maturity. ${ }^{7}$

In contrast, collateral composition significantly affected both loan amount and loan-to-collateral ratio. As the first column shows, asset-backed securities, commercial real estate, international securities, Treasuries, private mortgage-back securities, and consumer loans are associated with larger loans, whereas municipal securities are correlated with smaller loans. However, given that the regressions do not control for bank characteristics, it is likely that some of the collateral results are driven by omitted variables. For example, if larger banks are also more likely to hold asset-backed securities or international bonds, then the positive coefficient in Column 1 might be capturing the simple correlation between bank size and loan amount. In an attempt to address this concern, the regression specification reported in Column 2 adds bank fixed-effects to the analysis and hence uses variation within bank from repeated loans in several TAF auctions over time. Indeed, as the second column of the table demonstrates, only commercial real estate, Treasury, and private MBS survive the addition of fixed-effects and are still positive and significant. In addition, residential mortgages and corporate bonds turn out to be positive and significant when fixed-effects are added.

Turning to the last two columns of the table, I find that loans secured by asset-backed securities obtained loan-to-collateral ratios that are between -0.150 and -0.052 lower. Likewise, consumer loans led to lower loan-to-value ratios, while loans secured by Treasuries had loan-to-collateral ratios that were higher by 0.030 . The results are consistent with the notion that haircuts on collateral are used as an important tool for monetary policy. This is important especially when non traditional monetary policy is conducted through auctions in which the interest rate and loan terms do not vary across borrowers.

\footnotetext{
${ }^{7}$ The high R-squared in the interest rate is completely driven by the year $\times$ month fixed-effects since there was an overall trend of declining interest rates throughout the TAF time period.
} 


\subsection{The Evolution of TAF over Time}

Figure 1 displays the evolution of the TAF lending facility size over time. As described in Section 2, the Federal Reserve Bank announced in advance the offering amount in each auction. As Figure 1 shows, the initial auctions were smaller, with amounts that were between $\$ 20$ and $\$ 30$ billion. The offering amount was raised to $\$ 50$ billion in the auction of March 10, 2008, and was further increased to $\$ 75$ billion on May 5th, 2008. While the amounts fluctuated between $\$ 25$ and $\$ 75$ billion in August and September 2008, the lending facilities increased dramatically to $\$ 150$ billion on October 6, 2008, during the peak of the financial crisis, and remained at that level until the end of June 2009. The offering amount gradually declined to $\$ 125$ and $\$ 100$ billion in July and August 2009 , respectively, and later fluctuated between $\$ 75$ and $\$ 25$ billion. The final auction was held on March 8, 2010 for $\$ 25$ billion.

Although Figure 1 plots the offering amounts in each of the auctions and hence the potential (the supply of funds), it does not show the amount demanded by banks that submitted bids for TAF money or the amount that was actually loaned. Figure 2 supplements the information in Figure 1 by plotting both the total amount of proposition submitted by banks (the demand for loans) (dashed line) and the amount that was actually awarded (solid line). ${ }^{8}$ As the figure illustrates, the demand for funds exceeded the supply from the first auction in December 2007 until the auction of September 22, 2008. For example, on December 12, 2007, the offering amount by the Federal Reserve was $\$ 20$ billion, but the amount demanded by the 93 banks that submitted bids was $\$ 61.6$ billion. In the auction of September 22, 2008, the facility was increased to $\$ 75$ billion, but 85 banks submitted bids totaling $\$ 133.6$ billion.

Following the Federal Reserve's increase of the facility size to $\$ 150$ billion in October 2008, the amount of propositions submitted by banks was lower than the amount offered by the Federal Reserve Bank until the end of the TAF. In the October 8, 2008, auction - the first auction with a facility size of $\$ 150$ billion - 71 banks submitted bids totaling $\$ 138.1$ billion. The largest amount requested by banks was $\$ 142.5$ billion, when 117 banks participated in the auction of February 9, 2009. The largest number of banks participating in a single auction was 124 (May 4, 2009), compared to only 16 banks on November 24, 2008.

\footnotetext{
${ }^{8}$ I use the notion of demand and supply here fairly loosely. Of course, given the auction structure, there was no excess demand at a given rate.
} 


\subsection{TAF Lending to Foreign Banks}

Table 5 lists the number of loans, average loan size, and total amount loaned in each month from the first auction in December 2007 through the final auction in March 2010. The table further breaks down monthly lending by whether the borrowing bank is a U.S. depository institution or a foreign bank. ${ }^{9}$ Overall, foreign banks amounted for 58 percent of the overall amount lent over time, with a total amount of $\$ 2,214.688$ million, compared to only $\$ 1,603,723$ for U.S. banks. From December 2007 through most of 2008, foreign banks accounted for the vast majority of the lending, with amounts that were between twofold and fourfold the total lending to U.S. banks. However, during the peak of the crisis and following the collapse of Lehman Brothers, and especially in October and November 2008, lending to U.S. banks exceeded borrowing by foreign banks. By April 2008 and until the end of the TAF, foreign banks accounted again for the majority of TAF lending.

Table 6 and Figure 3 present the fifty largest borrowers (measured by the total amount borrowed). For each of the largest borrowers, Table 6 lists the total loan amount, the average loan size, the number of loans obtained under the TAF, and the home country of the bank. Likewise, Figure 3 displays the largest fifty borrowers in a bar chart. As both Table 6 and Figure 6 show, U.K.based Barclays is the largest borrower, with a total amount of $\$ 232,283$ million in forty-nine loans, followed by Bank of America, with a total amount of $\$ 212,617$ million in fifteen loans. The next largest borrowers are Royal Bank of Scotland (\$180,920 million), Wells Fargo (\$153,953 million), and Wachovia (\$147,025 million). Furthermore, out of the ten largest borrowers, five are foreign bank and out of the fifty largest borrowers, thirty-three are from foreign countries.

\subsection{The Collateral Structure of Foreign Banks}

As I argued previously, the loan term and interest rate were determined at the auction level regardless of the identity of the borrowing bank participating in the auction. In contrast, the size of the loan and the collateral pledged by the bank were the only margins that both the bank and the Federal Reserve Bank could adjust at the loan level. Given the importance of collateral in general and in particular given the unique setup of the TAF, I now compare the collateral structure of domestic banks to the collateral used by foreign banks. Table 7 presents summary statistics on the usage of collateral by domestic and foreign banks. For each asset category reported by the Federal Reserve the table lists the mean share of the asset category in the collateral pool, the standard

\footnotetext{
${ }^{9}$ Foreign banks were eligible to participate in the TAF through their agencies or branches in the United States.
} 
deviation of the share, and the number of loans pledging this asset as part of their collateral.

The summary statistics are reported separately for domestic and foreign banks, and a twosample T-test for equal means is also presented. As Table 7 shows, foreign banks rarely used residential mortgages as collateral - only 5 loans made to foreign banks were secured by residential mortgages, compared to 460 loans to domestic banks. On the other hand, asset-backed securities were used in 983 loans to foreign banks, compared to 318 loans to domestic banks. Furthermore, asset-backed securities account for a larger share of the overall collateral pool in foreign banks (9.323 versus 0.151 , significant at the 1 percent level). As in the case of residential mortgages, foreign banks used consumer loans in only 44 loans, while U.S.-based banks had consumer loans in 1,043 loans. Private MBS/CMO are more prevalent in foreign banks (although their share is slightly lower than in U.S. banks), and commercial real estate loans were used in only 222 foreign loans. Other significant differences between foreign and domestic banks are that foreign banks were less likely to use Agency MBS/CMO, U.S. Treasury/Agency, and U.S. municipal bonds and were much more likely to pledge international securities as collateral.

Table 8 supplements the results in Table 7 using regression analysis of the collateral composition of foreign banks. For each of the main asset categories I use two dependent variables. The first dependent variable is a dummy variable for whether a security type is pledged as collateral for a particular loan - this variable captures the average tendency to use an asset as collateral. The second dependent variable is the actual share of the collateral in each asset group conditional on the asset being used as collateral. That is, while the first variable uses information on all loans, the second variables captures only the cross-sectional variation within an asset category conditional on its use. All regressions include year $\times$ month fixed-effects as well as a control for the loan amount (in logs) and a dummy variable that takes the value of one for foreign banks, and zero otherwise. Regressions for which the dependent variable is a dummy variable are estimated using probit where marginal effects are reported. Table 8 confirms the univariate findings. Foreign banks are more likely to use asset-backed securities, international assets, and Treasuries and are less likely to use commercial real-estate. 


\section{Why FOREIGN BANKS?}

Given that more than 58 percent of TAF lending went to foreign banks, it is important to understand why the Federal Reserve allocated its lending to foreign banks that are not under its direct supervision. In addition, the information contained in the collateral structure of these banks suggests that the collateral pledged by the foreign banks consisted of harder-to-value, riskier assets such as asset-backed-securities. In particular, ABS held by the foreign banks are - according to the data definitions provided by the Federal Reserve Board - collateralized debt obligations secured by ABS, which were the securitized assets that declined the most during the crisis (Benmelech and Dlugosz (2009)).

\subsection{Exposure to Asset-Backed Securities}

One potential explanation for both the elevated lending to foreign banks and their usage of assetbacked securities as collateral is that foreign banks were hit harder than U.S. banks and hence required more liquidity. Given that many of these banks had exposure to assets that deteriorated in value - mostly ABS and CDOs - these banks had weaker balance sheets.

However, foreign banks were not the only banks that were exposed to ABS CDOs. Table 9 provides information on aggregate crisis-related write-downs as well as write-downs for some of the largest financial institutions in the world. ${ }^{10}$ As the table demonstrates, as of October 2008, Citigroup had written down $\$ 34.1$ billion as a result of exposure to ABS CDOs, followed by Merrill Lynch with $\$ 26.1$ billion, and Bank of America ( $\$ 9.1$ billion). As of February 2009, the total value of write-downs by financial institutions around the world was $\$ 520.1$ billion, out of which $\$ 218.2$ billion were due to exposure to ABS CDOs, representing 42 percent of total write-downs by the financial sector. Write-downs driven by ABS CDOs were more than four times the size of corporate credit-related write-downs. North American Banks accounted for the largest share of ABS CDOs write-downs, followed by European banks. The European bank with the largest exposure to ABS was UBS ( $\$ 21,870$ million), followed by Fortis Banks ( $\$ 4,359$ million), Royal Bank of Scotland (\$3,609 millon) and Deutsche Bank (\$2,092 million).

If banks that were more likely to participate in the TAF were those that had worse balance sheets

\footnotetext{
${ }^{10}$ The data are from Creditflux, a leading information source globally for credit trading and investing, credit derivatives, structured credit, distressed credit, and credit research. This table is based on the results presented in Benmelech and Dlugosz (2009).
} 
due to exposure to structured finance products, we should expect the institutions with the most exposure to ABS CDOs to borrow more under the TAF and pledge these securities as collateral. However, mere exposure to structured finance assets does not seem to explain either the amount of borrowing or the collateral used by the banks.

Table 10 lists the fifty banks that pledged the largest amounts of asset-backed securities per loan. As the table clearly shows, and consistent with Tables 7 and 8, most of the banks and financial institutions that pledged ABS as collateral were foreign - mostly European - banks. For example, the bank that pledged the largest amount of ABS for a given loan was Société Générale (France), followed by Norinchukin Bank (Japan), Dexia (Belgium), Barclays (U.K.), and UBS (Switzerland). Among the ten banks that pledged the largest amounts of asset-backed securities as collateral, only two were American banks (State Street and U.S. Central Federal Credit Union).

In contrast, the American banks that had the largest exposure and write-downs due to ABS CDOs - Citigroup and Bank of America - had only modest borrowing secured by ABS. For example, as Table 9 demonstrates, Citibank had the largest write downs due to ABS CDOs borrowed against $\$ 760.8$ million of ABS, compared to Société Générale with $\$ 16,352.0$ million and UBS with $\$ 9,419.0$ million. Thus, despite their exposure to ABS and structured finance assets, American banks were less likely to obtain term funding through the TAF or to pledge asset-backed securities as collateral.

\subsection{The European Banks' Dollar Crisis}

Another explanation for the large number of loans made to foreign banks is that these banks suffered from a currency mismatch in their balance sheets. Many foreign banks were active players in the creation and issuance of structured finance products. As money markets came to a halt, these banks required financing to meet the needs of rolling over their short-term liabilities. Moreover, foreign banks were also subject to a currency mismatch in managing their assets and liabilities. Although the main source of funding for some of these banks was based on demand deposits and other forms of credit in their home countries that were denominated in their home currencies mostly the British pound and euro - many European banks issued liabilities in U.S. money markets that were denominated in the U.S. dollar. Thus, not only were foreign banks subject to a roll-over risk, but they also suffered from a currency mismatch and had to rely on special facilities such as the currency swap lines between central banks including the European Central Bank, Bank of England, Swiss National Bank, and Federal Reserve Bank, as well as special lending programs such 
as the TAF.

Indeed, foreign banks have played an important role in American financial markets during the years leading to the financial crisis. According to Shin (2011): "The US-dollar denominated assets of banks outside the United States are comparable in size to the total assets of the US commercial banking sector, peaking at over $\$ 10$ trillion prior to the crisis. The BIS banking statistics reveal that a substantial portion of external U.S. dollar claims are the claims of European banks against US counterparties." Likewise, studies from the Bank for International Settlements (BIS) by Baba, McCauley, and Ramaswamy (2009) and McGuire and von Peter (2009) show that US dollar wholesale deposits and money market funds were an important source of funding for European global banks in the years leading to the crisis.

Moreover, Shin (2011) provides evidence based on data from the BIS that European global banks raised their assets in the United States in the years leading to the crisis, increasing their claims against U.S. borrowers by almost 40 percent from 2005 to 2007. Although European banks had access to U.S. credit markets, they still had their core funding in their home countries in European currencies. It was the currency mismatch between their assets - many in the form of private-label ABS and CDOs - and their liabilities that made them vulnerable to the halt in U.S. short-term lending markets.

According to this view, European banks were more likely to bid for TAF money because they were affected more severely by the financial crisis, given their exposure to currency mismatch between assets and liabilities. Shin (2011) draws similar conclusions from the fact that a large fraction of TAF lending was originated to European banks. He writes:

Two features stand out from the charts in Figure 11. The first is that the non-US banks' total borrowing is large relative to US banks' borrowing. The relative magnitudes are roughly comparable at the peak. The second feature that stands out is the preponderance of European banks in the list of non-US recipients of TAF funding. The UK banks are especially prominent, led by Barclays, RBS and Bank of Scotland. The list also reveals some unlikely names, such as Norinchukin (the Agricultural Savings Bank of Japan) and the German landesbanks, who are likely to have ventured into US dollar lending in their search for higher yielding assets to deploy their large domestic deposit bases. (Shin 2011, 17-18) 
Thus, it is likely that the elevated lending to foreign banks and in particular to European banks reflects their prominent role in the U.S. financial system, their involvement in the structured finance markets - especially the private-name ABS and CDOs - and the currency mismatch in their balance sheets.

\section{CONCLUSiON}

This paper provides detailed analysis of the Term Auction Facility plan using micro-level data on the individual loans, the assets posted as collateral, and the identity of the borrowing banks. I find that foreign banks accounted for about 60 percent of TAF lending and that the largest borrowers in the program were mostly European banks. Moreover, most of the banks that pledged asset-backed securities as collateral were European banks.

I argue that the main reason for the large number of loans made to foreign banks is that European banks suffered from a currency mismatch in their balance sheets. Many European banks were active players in the creation and issuance of structured finance products, and as money markets came to a halt, these banks required financing to meet the needs of rolling over their shortterm liabilities. These European banks were also subject to a currency mismatch in managing their assets and liabilities. Although the main source of funding for some of these banks was based on demand deposits and other forms of credit in their home-countries that were denominated in their home currencies, they issued liabilities in U.S. money markets that were denominated in the U.S. dollar. Thus, foreign banks not only were subject to a roll-over risk but also suffered from a currency mismatch and had to rely special facilities such as the TAF.

The data illustrate the scale of the operation of foreign - in particular European - banks in U.S. financial markets. What precise role do European banks play in the American economy? What led to their involvement in the U.S. financial system? These questions are left for future research. 


\section{References}

Baba, Naohiko, Robert N. McCauley, and Srichander Ramaswamy. 2009. "US Dollar Money Market Funds and Non-US Banks." BIS Quarterly Review, March 2009, 65-81.

Benmelech, Efraim, and Jennifer Dlugosz. 2009. "The Credit Rating Crisis," NBER Macro Annual 2009, 161-207.

Bernanke, B. 2009 "The Federal Reserve's Balance Sheet: An Update." Speech at the Federal Reserve Board Conference on Key Developments in Monetary Policy, Washington, D.C.

McAndrews, James, Asani Sarkar, and Zhenyu Wang. 2008. "The Effect of the Term Auction Facility on the London Inter-Bank Offered Rate." Staff Report no. 335, Federal Reserve Bank of New York Staff Reports.

McGuire, Patrick, and Goetz von Peter. 2009. "The US Dollar Shortage in Global Banking." BIS Quarterly Review, Bank for International Settlements.

Shin, Hyun Song. 2011. "Global Banking Glut and Loan Risk Premium." 2011 Mundell-Fleming Lecture Conference Draft.

Taylor, John B., and John C. Williams. 2008. "A Black Swan in the Money Market." American Economic Journal: Macroeconomic 1: 58-83. 


\section{Table 1:}

\section{Loan Characteristics}

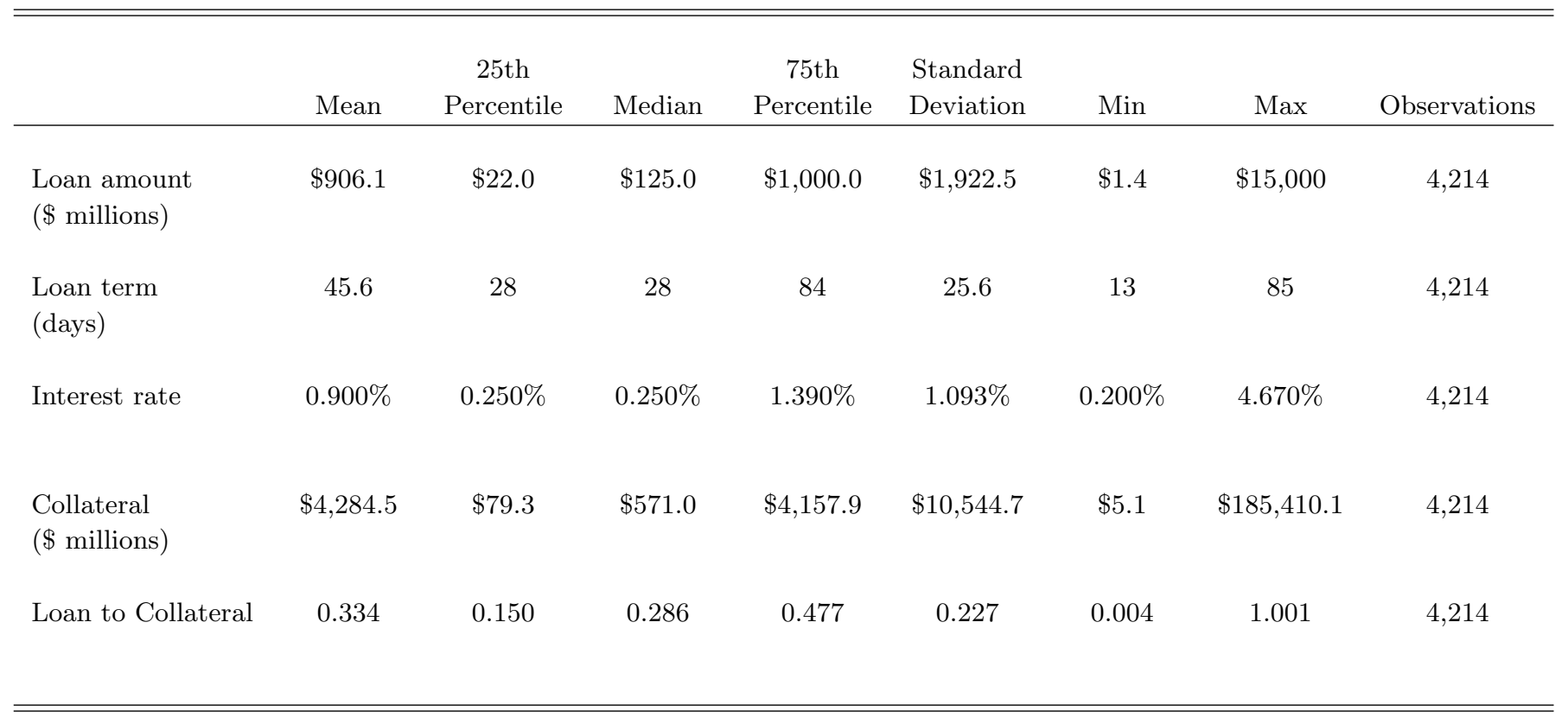


Table 2:

Collateral Composition by Security Type (\$ millions)

\begin{tabular}{|c|c|c|c|c|c|c|c|c|}
\hline & Mean & $\begin{array}{c}25 \text { th } \\
\text { Percentile }\end{array}$ & Median & $\begin{array}{c}\text { 75th } \\
\text { Percentile }\end{array}$ & $\begin{array}{l}\text { Standard } \\
\text { Deviation }\end{array}$ & Min & Max & Observations \\
\hline Residential mortgages & $\$ 3,786.3$ & $\$ 7.9$ & $\$ 27.5$ & $\$ 402.9$ & $\$ 11,070$ & $\$ 0.0$ & $\$ 76,847.5$ & 465 \\
\hline $\mathrm{ABS}$ & $\$ 2,562.8$ & $\$ 91.5$ & $\$ 780.6$ & $\$ 2,513.4$ & $\$ 4,486.9$ & $\$ 0.4$ & $\$ 25,953.7$ & 1,301 \\
\hline Commercial loans & $\$ 2,232.1$ & $\$ 40.1$ & $\$ 338.0$ & $\$ 1,544.4$ & $\$ 6,911.8$ & $\$ 0.1$ & $\$ 76,784$ & 2,291 \\
\hline Consumer loans & $\$ 1,462.5$ & $\$ 8.8$ & $\$ 86.1$ & $\$ 1,194.1$ & $\$ 3,875.5$ & $\$ 0.0$ & $\$ 32,679.2$ & 1,087 \\
\hline Private MBS/CMO & $\$ 1,154.9$ & $\$ 69.6$ & $\$ 241.7$ & $\$ 922.5$ & $\$ 2,378.8$ & $\$ 0.0$ & $\$ 14,599.2$ & 1,045 \\
\hline Commercial real estate & $\$ 1,091.0$ & $\$ 35.9$ & $\$ 104.3$ & $\$ 718.9$ & $\$ 2,471.5$ & $\$ 0.0$ & $\$ 30,469.6$ & 1,624 \\
\hline Corporate & $\$ 747.6$ & $\$ 43.6$ & $\$ 209.3$ & $\$ 1,115.9$ & $\$ 1,090.0$ & $\$ 0.1$ & $\$ 6,840.6$ & 1,507 \\
\hline International securities & $\$ 703.1$ & $\$ 28.7$ & $\$ 129.7$ & $\$ 580.4$ & $\$ 1,492.0$ & $\$ 0.1$ & $\$ 11,302.5$ & 1,138 \\
\hline Agency MBS/CMO & $\$ 567.9$ & $\$ 12.2$ & $\$ 80.2$ & $\$ 498.7$ & $\$ 1,681.2$ & $\$ 0.0$ & $\$ 26,679.8$ & 1,151 \\
\hline Municipals & $\$ 370.3$ & $\$ 7.0$ & $\$ 20.1$ & $\$ 93.6$ & $\$ 1,180.6$ & $\$ 0.0$ & $\$ 8,911.9$ & 1,099 \\
\hline U.S Treasury/Agency & $\$ 348.8$ & $\$ 11.3$ & $\$ 48.5$ & $\$ 241.6$ & $\$ 968.7$ & $\$ 0.0$ & $\$ 8,762.4$ & 833 \\
\hline
\end{tabular}


Table 3:

Collateral Composition by Credit Rating (\$ millions)

\begin{tabular}{|c|c|c|c|c|c|c|c|c|}
\hline & Mean & $\begin{array}{c}25 \text { th } \\
\text { Percentile }\end{array}$ & Median & $\begin{array}{c}\text { 75th } \\
\text { Percentile }\end{array}$ & $\begin{array}{l}\text { Standard } \\
\text { Deviation }\end{array}$ & Min & $\operatorname{Max}$ & Observations \\
\hline \multicolumn{9}{|l|}{ AAA-rated } \\
\hline $\begin{array}{l}\text { U.S Treasury/Agency/ } \\
\text { Agency MBS-CMOs }\end{array}$ & $\$ 650.3$ & $\$ 13.4$ & $\$ 106.1$ & $\$ 555.8$ & $\$ 1,709.2$ & $\$ 0.0$ & $\$ 26,679.8$ & 1,375 \\
\hline Other AAA-rated & $\$ 1,845.8$ & $\$ 22.2$ & $\$ 352.9$ & $\$ 1,801.7$ & $\$ 3,532.8$ & $\$ 0.0$ & $\$ 22,364.7$ & 1,859 \\
\hline AA-rated & $\$ 381.6$ & $\$ 7.9$ & $\$ 74.2$ & $\$ 370.9$ & $\$ 857.8$ & $\$ 0.0$ & $\$ 8,505.2$ & 1,681 \\
\hline A-rated & $\$ 386.5$ & $\$ 13.3$ & $\$ 96.3$ & $\$ 420.8$ & $\$ 783.3$ & $\$ 0.1$ & $\$ 7,775.7$ & 1,817 \\
\hline BBB-rated & $\$ 238.0$ & $\$ 12.2$ & $\$ 68.5$ & $\$ 296.8$ & $\$ 422.9$ & $\$ 0.1$ & $\$ 4,881.4$ & 1,694 \\
\hline $\begin{array}{l}\text { Other } \\
\text { investment grade }\end{array}$ & $\$ 1,232.6$ & $\$ 42.3$ & $\$ 295.7$ & $\$ 1,088.1$ & $\$ 2,714.3$ & $\$ 0.0$ & $\$ 22,726.2$ & 1,417 \\
\hline
\end{tabular}


Table 4:

Determinants of Loan Terms

\begin{tabular}{|c|c|c|c|c|c|c|c|c|}
\hline & \multicolumn{2}{|c|}{$\begin{array}{c}\text { log } \\
\text { (loan amount) }\end{array}$} & \multicolumn{2}{|c|}{$\begin{array}{l}\text { interest } \\
\text { rate }\end{array}$} & \multicolumn{2}{|c|}{$\begin{array}{l}\text { loan } \\
\text { term }\end{array}$} & \multicolumn{2}{|c|}{$\begin{array}{c}\text { loan to } \\
\text { collateral }\end{array}$} \\
\hline & between & within & between & within & between & within & between & within \\
\hline ABS dummy & $\begin{array}{c}1.570 * * * \\
(0.084)\end{array}$ & $\begin{array}{l}-0.001 \\
(0.088)\end{array}$ & $\begin{array}{c}0.008 \\
(0.006)\end{array}$ & $\begin{array}{l}-0.016 \\
(0.020)\end{array}$ & $\begin{array}{c}0.444 \\
(1.152)\end{array}$ & $\begin{array}{c}0.544 \\
(2.708)\end{array}$ & $\begin{array}{c}-0.150 * * * \\
(0.010)\end{array}$ & $\begin{array}{c}-0.052 * * * \\
\quad(0.019)\end{array}$ \\
\hline International dummy & $\begin{array}{c}0.850 * * * \\
(0.082)\end{array}$ & $\begin{array}{c}0.047 \\
(0.069)\end{array}$ & $\begin{array}{l}-0.007 \\
(0.007)\end{array}$ & $\begin{array}{l}-0.008 \\
(0.014)\end{array}$ & $\begin{array}{c}2.417 * * \\
(1.122)\end{array}$ & $\begin{array}{l}-0.775 \\
(1.967)\end{array}$ & $\begin{array}{c}0.004 \\
(0.011)\end{array}$ & $\begin{array}{l}-0.005 \\
(0.016)\end{array}$ \\
\hline Municipal dummy & $\begin{array}{c}-0.242 * * * \\
(0.059)\end{array}$ & $\begin{array}{l}-0.017 \\
(0.059)\end{array}$ & $\begin{array}{c}0.002 \\
(0.004)\end{array}$ & $\begin{array}{c}0.017 \\
(0.011)\end{array}$ & $\begin{array}{l}-1.396 \\
(0.899)\end{array}$ & $\begin{array}{l}-2.951 * \\
(1.762)\end{array}$ & $\begin{array}{c}0.011 \\
(0.008)\end{array}$ & $\begin{array}{l}-0.022 \\
(0.014)\end{array}$ \\
\hline Treasury dummy & $\begin{array}{c}0.279 * * * \\
(0.067)\end{array}$ & $\begin{array}{c}0.217^{* * *} \\
(0.062)\end{array}$ & $\begin{array}{l}-0.004 \\
(0.005)\end{array}$ & $\begin{array}{l}-0.005 \\
(0.010)\end{array}$ & $\begin{array}{l}-1.170 \\
(0.998)\end{array}$ & $\begin{array}{l}-2.762 \\
(1.899)\end{array}$ & $\begin{array}{c}0.051 * * * \\
(0.009)\end{array}$ & $\begin{array}{c}0.030 * * \\
(0.014)\end{array}$ \\
\hline Agency dummy & $\begin{array}{c}0.046 \\
(0.062)\end{array}$ & $\begin{array}{c}0.048 \\
(0.057)\end{array}$ & $\begin{array}{l}-0.003 \\
(0.004)\end{array}$ & $\begin{array}{l}-0.008 \\
(0.009)\end{array}$ & $\begin{array}{c}0.088 \\
(0.960)\end{array}$ & $\begin{array}{c}-3.398 * * \\
(1.673)\end{array}$ & $\begin{array}{c}0.004 \\
(0.009)\end{array}$ & $\begin{array}{c}0.002 \\
(0.013)\end{array}$ \\
\hline $\begin{array}{l}\text { Residential } \\
\text { mortgages dummy }\end{array}$ & $\begin{array}{c}0.035 \\
(0.095)\end{array}$ & $\begin{array}{c}0.324^{* * *} \\
(0.108)\end{array}$ & $\begin{array}{l}-0.000 \\
(0.005)\end{array}$ & $\begin{array}{c}0.024 \\
(0.020)\end{array}$ & $\begin{array}{c}-6.267 \text { *** } \\
(1.105)\end{array}$ & $\begin{array}{c}-7.223 * * * \\
(2.549)\end{array}$ & $\begin{array}{c}0.052 \text { *** } \\
(0.012)\end{array}$ & $\begin{array}{c}-0.037 * \\
(0.022)\end{array}$ \\
\hline $\begin{array}{l}\text { Consumer } \\
\text { loans dummy }\end{array}$ & $\begin{array}{c}0.454 * * * \\
(0.070)\end{array}$ & $\begin{array}{c}0.203 * * \\
(0.103)\end{array}$ & $\begin{array}{l}-0.003 \\
(0.004)\end{array}$ & $\begin{array}{l}-0.005 \\
(0.017)\end{array}$ & $\begin{array}{c}0.959 \\
(0.865)\end{array}$ & $\begin{array}{c}-4.037 * \\
(2.401)\end{array}$ & $\begin{array}{c}-0.073^{* * *} \\
(0.008)\end{array}$ & $\begin{array}{c}-0.063 \text { *** } \\
(0.020)\end{array}$ \\
\hline $\begin{array}{l}\text { Corporate } \\
\text { securities dummy }\end{array}$ & $\begin{array}{c}0.111 \\
(0.077)\end{array}$ & $\begin{array}{c}0.340 * * * \\
(0.082)\end{array}$ & $\begin{array}{c}0.007 \\
(0.006)\end{array}$ & $\begin{array}{c}0.007 \\
(0.015)\end{array}$ & $\begin{array}{l}-1.613 \\
(1.091)\end{array}$ & $\begin{array}{c}1.740 \\
(2.192)\end{array}$ & $\begin{array}{c}0.047^{* * *} \\
(0.011)\end{array}$ & $\begin{array}{c}-0.034 * \\
(0.020)\end{array}$ \\
\hline \multicolumn{9}{|l|}{ Fixed-Effects } \\
\hline
\end{tabular}

Omitted collateral category is commercial loans. 
Table 5:

Evolution of the TAF over Time: Foreign Banks versus Domestic Banks

\begin{tabular}{|c|c|c|c|c|c|c|}
\hline & $\begin{array}{l}\text { Number } \\
\text { of Loans }\end{array}$ & $\begin{array}{l}\text { Average } \\
\text { Loan size }\end{array}$ & $\begin{array}{c}\text { Total } \\
\text { Amount }\end{array}$ & $\begin{array}{l}\text { Number } \\
\text { of Loans }\end{array}$ & $\begin{array}{l}\text { Average } \\
\text { Loan size }\end{array}$ & $\begin{array}{c}\text { Total } \\
\text { Amount }\end{array}$ \\
\hline & \multicolumn{3}{|c|}{ Domestic banks } & \multicolumn{3}{|c|}{ Foreign banks } \\
\hline December 2007 & 13 & $\$ 374.9$ & $\$ 4,873$ & 42 & $\$ 836.4$ & $\$ 35,127$ \\
\hline January 2008 & 46 & $\$ 460.3$ & $\$ 21,172$ & 35 & $\$ 1,109.4$ & $\$ 38,828$ \\
\hline February 2008 & 41 & $\$ 423.6$ & $\$ 17,368$ & 34 & $\$ 1,253.9$ & $\$ 42,632$ \\
\hline March 2008 & 45 & $\$ 615.2$ & $\$ 27,683$ & 41 & $\$ 1,763.8$ & $\$ 72,318$ \\
\hline April 2008 & 32 & $\$ 487.5$ & $\$ 15,560$ & 44 & $\$ 1,918.2$ & $\$ 84,400$ \\
\hline May 2008 & 76 & $\$ 729.2$ & $\$ 55,418$ & 56 & $\$ 1,669.0$ & $\$ 94,581$ \\
\hline June 2008 & 57 & $\$ 848.0$ & $\$ 48,335$ & 50 & $\$ 2,033.3$ & $\$ 101,665$ \\
\hline July 2008 & 105 & $\$ 821.2$ & $\$ 86,230$ & 79 & $\$ 1,756.6$ & $\$ 138,770$ \\
\hline August 2008 & 73 & $\$ 912.7$ & $\$ 66,627$ & 55 & $\$ 1,515.9$ & $\$ 83,373$ \\
\hline September 2008 & 40 & $\$ 1,064.9$ & $\$ 42,595$ & 46 & $\$ 1,791.4$ & $\$ 82,405$ \\
\hline October 2008 & 86 & $\$ 1,730.4$ & $\$ 148,818$ & 61 & $\$ 1,681.1$ & $\$ 102,545$ \\
\hline November 2008 & 113 & $\$ 1,394.4$ & $\$ 157,561$ & 60 & $\$ 1,430.9$ & $\$ 85.856$ \\
\hline December 2008 & 124 & $\$ 608.2$ & $\$ 75,412$ & 61 & $\$ 1,602.9$ & $\$ 97,776$ \\
\hline January 2009 & 185 & $\$ 1,062.8$ & $\$ 196,617$ & 89 & $\$ 1,687.2$ & $\$ 150,160$ \\
\hline February 2009 & 150 & $\$ 1,025.6$ & $\$ 153,838$ & 66 & $\$ 1,519.7$ & $\$ 100,302$ \\
\hline March 2009 & 149 & $\$ 689.6$ & $\$ 102,743$ & 71 & $\$ 1,643.3$ & $\$ 116,672$ \\
\hline April 2009 & 136 & $\$ 608.4$ & $\$ 82,743$ & 67 & $\$ 1,602.8$ & $\$ 107,386$ \\
\hline May 2009 & 159 & $\$ 568.8$ & $\$ 90,446$ & 61 & $\$ 1,584.1$ & $\$ 96,633$ \\
\hline June 2009 & 140 & $\$ 258.5$ & $\$ 36,195$ & 62 & $\$ 1,723.5$ & $\$ 107,416$ \\
\hline July 2009 & 210 & $\$ 240.1$ & $\$ 50,417$ & 87 & $\$ 1,908.8$ & $\$ 166,062$ \\
\hline August 2009 & 132 & $\$ 192.2$ & $\$ 25,371$ & 56 & $\$ 1,624.5$ & $\$ 90,974$ \\
\hline September 2009 & 109 & $\$ 210.2$ & $\$ 22,912$ & 49 & $\$ 1,321.6$ & $\$ 64,759$ \\
\hline October 2009 & 116 & $\$ 192.5$ & $\$ 22,326$ & 42 & $\$ 1,001.7$ & $\$ 42,070$ \\
\hline November 2009 & 104 & $\$ 160.7$ & $\$ 16,713$ & 31 & $\$ 889.0$ & $\$ 27,558$ \\
\hline December 2009 & 110 & $\$ 155.8$ & $\$ 17,140$ & 41 & $\$ 1,112.8$ & $\$ 45,625$ \\
\hline January 2010 & 98 & $\$ 111.2$ & $\$ 10,893$ & 23 & $\$ 1,201.7$ & $\$ 27,638$ \\
\hline February 2010 & 89 & $\$ 64.8$ & $\$ 5,763$ & 14 & $\$ 690.2$ & $\$ 9,663$ \\
\hline March 2010 & 49 & $\$ 39.1$ & $\$ 1,914.7$ & 4 & $\$ 373.8$ & $\$ 1,495$ \\
\hline December 2007-March 2010 & 2,787 & $\$ 575.4$ & $\$ 1,603,723$ & 1,427 & $\$ 1,552.0$ & $\$ 2,214,688$ \\
\hline
\end{tabular}


Table 6:

Largest Borrowers (in \$ millions)

\begin{tabular}{|c|c|c|c|c|c|}
\hline & Bank & $\begin{array}{c}\text { Total } \\
\text { Loans Amount }\end{array}$ & $\begin{array}{l}\text { Average } \\
\text { Loan Size }\end{array}$ & $\begin{array}{l}\text { Number } \\
\text { of Loans }\end{array}$ & Country \\
\hline 1. & Barclays & 232,283 & $4,740.5$ & 49 & United Kingdom \\
\hline 2. & Bank of America & 212,617 & $14,144.5$ & 15 & U.S. \\
\hline 3. & Royal Bank of Scotland & 180,920 & 4,523 & 40 & United Kingdom \\
\hline 4. & Wells Fargo & 153,953 & $8,102.9$ & 19 & U.S. \\
\hline 7. & Dresdner Bank & $123,328.2$ & $3,333.2$ & 37 & Germany \\
\hline 8. & RBS Citizens & 117,510 & $4,039.7$ & 29 & U.S . \\
\hline 9. & Citibank & $110,349.7$ & $4,244.2$ & 26 & U.S. \\
\hline 10. & Bayerische Landesbank & 108,190 & $2,924.1$ & 37 & Germany \\
\hline 11. & Dexia & $105,166.8$ & $4,382.0$ & 24 & Belgium \\
\hline 15. & Deutsche Bank & 76,882 & $3,844.1$ & 20 & Germany \\
\hline 16. & Regions Bank & $72,443.5$ & $3,149.7$ & 23 & U.S. \\
\hline 17. & Unicredit & 62,210 & $2,592.1$ & 24 & Italy \\
\hline 18. & Fortis Bank & 58,650 & 1,725 & 34 & Belgium \\
\hline 19. & Sumitomo & 56,400 & $1,151.0$ & 49 & Japan \\
\hline 20. & UBS & 55,500 & $3,468.8$ & 16 & Switzerland \\
\hline 21. & Royal Bank of Scotland & 53,500 & $8,916.7$ & 6 & United Kingdom \\
\hline 22. & HSH Nordbank & 52,550 & $1,545.6$ & 34 & Germany \\
\hline 23. & Mizuho & $51,284.2$ & $1,091.2$ & 47 & Japan \\
\hline 24. & Commerzbank & $51,161.2$ & $2,046.5$ & 25 & Germany \\
\hline 25. & Depfa Bank & 46,798 & $2,600.0$ & 18 & Ireland \\
\hline 32. & Bank of Tokyo Mitsubishi & 35,900 & $1,087.9$ & 33 & Japan \\
\hline 33. & Royal Bank of Canada & 34,734 & $1,085.4$ & 32 & Canada \\
\hline 34. & Allied Irish & 34,700 & $1,927.8$ & 18 & Ireland \\
\hline 35. & Bayerische Нуро & 34,390 & 802.1 & 43 & Germany \\
\hline 36. & Natixis & 32,817 & $1,131.6$ & 29 & France \\
\hline 37. & BNP Paribas & 31,275 & $1,303.1$ & 24 & France \\
\hline 38. & Toronto Dominion & 27,465 & $1,445.5$ & 19 & Canada \\
\hline 39. & Bank of Nova Scotia & $26,464.7$ & 661.6 & 40 & Canada \\
\hline 40. & Arab Banking Corporation & 26,350 & 572.8 & 46 & Bahrain \\
\hline 41. & Standard Chartered & 25,100 & 896.4 & 28 & United Kingdom \\
\hline 42. & Mitsubishi UFJ & $24,456.6$ & 444.7 & 55 & Japan \\
\hline 43. & Crédit Industriel et Commercial & 23,910 & 703.2 & 34 & France \\
\hline 44. & Rabobank & $23,750.6$ & $2,375.0$ & 10 & Netherlands \\
\hline 45. & $\mathrm{BB} \& \mathrm{~T}$ & 22,700 & $2,522.2$ & 9 & U.S . \\
\hline 56. & Landesbank Baden & 22,580 & $1,411.3$ & 16 & Germany \\
\hline 47. & Ally Bank & 21,600 & $1,963.6$ & 11 & U.S . \\
\hline 48. & Marshall \& Ilsley & $21,021.7$ & 841.8 & 25 & U.S \\
\hline 49. & Countrywide & 20,750 & $6,916.7$ & 3 & U.S \\
\hline 50. & Union Bank & 20,100 & $1,182.4$ & 17 & U.S . \\
\hline
\end{tabular}


Table 7:

\section{Collateral Share: Foreign Banks versus Domestic Banks}

\begin{tabular}{|c|c|c|c|c|c|c|c|c|}
\hline & Mean & $\begin{array}{l}\text { Standard } \\
\text { Deviation }\end{array}$ & $\begin{array}{c}\text { Number of } \\
\text { Loans }\end{array}$ & Mean & $\begin{array}{l}\text { Standard } \\
\text { Deviation }\end{array}$ & $\begin{array}{c}\text { Number of } \\
\text { Loans }\end{array}$ & Difference & $\begin{array}{c}\text { Two-sample } \\
\text { T-test }\end{array}$ \\
\hline & \multicolumn{3}{|c|}{ Domestic banks } & \multicolumn{3}{|c|}{ Foriegn banks } & & \\
\hline Residential mortgages & 0.280 & 0.01 & 460 & 0.733 & 0.01 & 5 & -0.454 & -3.368 \\
\hline Asset-backed Securities & 0.151 & 0.01 & 318 & 0.323 & 0.01 & 983 & -0.172 & -11.34 \\
\hline Commercial loans & 0.470 & 0.01 & 1,656 & 0.427 & 0.02 & 635 & 0.043 & 2.83 \\
\hline Consumer loans & 0.358 & 0.01 & 1,043 & 0.477 & 0.07 & 44 & -0.119 & -2.15 \\
\hline Private MBS/CMO & 0.183 & 0.01 & 349 & 0.141 & 0.01 & 696 & 0.042 & 3.19 \\
\hline Commercial real estate & 0.563 & 0.01 & 1,402 & 0.159 & 0.01 & 222 & 0.404 & 20.37 \\
\hline Corporate securities & 0.192 & 0.01 & 428 & 0.263 & 0.01 & 1,079 & -0.071 & -4.74 \\
\hline International securities & 0.133 & 0.02 & 194 & 0.208 & 0.01 & 944 & -0.073 & -3.83 \\
\hline Agency MBS/CMO & 0.392 & 0.01 & 673 & 0.225 & 0.01 & 478 & 0.167 & 8.82 \\
\hline Municipals & 0.233 & 0.01 & 611 & 0.055 & 0.01 & 488 & 0.177 & 12.26 \\
\hline U.S. Treasury/Agency & 0.238 & 0.02 & 384 & 0.149 & 0.01 & 449 & 0.089 & 5.43 \\
\hline
\end{tabular}


Table 8:

Collateral Composition of Foreign Banks

\begin{tabular}{|c|c|c|c|c|c|c|c|c|}
\hline & \multicolumn{2}{|c|}{$\begin{array}{c}\text { Asset-backed } \\
\text { Securities }\end{array}$} & \multicolumn{2}{|c|}{$\begin{array}{l}\text { Commercial } \\
\text { Real Estate }\end{array}$} & \multicolumn{2}{|c|}{$\begin{array}{c}\text { International } \\
\text { Securities }\end{array}$} & \multicolumn{2}{|c|}{$\begin{array}{l}\text { Treasury } \\
\text { Securities }\end{array}$} \\
\hline & extensive & intensive & extensive & intensive & extensive & intensive & extensive & intensive \\
\hline Log (loan amount) & $\begin{array}{c}0.090 * * * \\
(0.004)\end{array}$ & $\begin{array}{c}0.025 * * * \\
(0.005)\end{array}$ & $\begin{array}{c}0.034 * * * \\
(0.004)\end{array}$ & $\begin{array}{c}-0.072 * * * \\
(0.003)\end{array}$ & $\begin{array}{c}0.018 * * * \\
(0.004)\end{array}$ & $\begin{array}{c}-0.008 * \\
(0.005)\end{array}$ & $\begin{array}{l}0.006 * \\
(0.004)\end{array}$ & $\begin{array}{c}-0.064 * * * \\
(0.005)\end{array}$ \\
\hline Foreign dummy & $\begin{array}{c}0.393 * * * \\
(0.018)\end{array}$ & $\begin{array}{c}0.143 * * * \\
(0.015)\end{array}$ & $\begin{array}{c}-0.403 * * * \\
(0.015)\end{array}$ & $\begin{array}{c}-0.231 * * * \\
(0.018)\end{array}$ & $\begin{array}{c}0.611 * * * \\
(0.017)\end{array}$ & $\begin{array}{c}0.136^{* * *} \\
(0.021)\end{array}$ & $\begin{array}{c}0.178 * * * \\
(0.016)\end{array}$ & $\begin{array}{c}0.082 * * * \\
(0.015)\end{array}$ \\
\hline \multicolumn{9}{|l|}{ Fixed-Effects } \\
\hline year $\times$ month & Yes & Yes & Yes & Yes & Yes & Yes & Yes & Yes \\
\hline Pseudo/Adjusted $R^{2}$ & 0.39 & 0.13 & 0.11 & 0.41 & 0.39 & 0.09 & 0.05 & 0.26 \\
\hline Observations & 4,214 & 1,301 & 4,214 & 1,624 & 4,214 & 1,138 & 4,214 & 833 \\
\hline
\end{tabular}


Table 9:

ABS CDOs and Write-Downs

\begin{tabular}{|c|c|c|c|c|c|}
\hline & ABS CDOs & $\begin{array}{c}\text { Corporate } \\
\text { credit }\end{array}$ & RMBS & Other & Total \\
\hline \multicolumn{6}{|l|}{ North American Banks } \\
\hline Bank of America & 9,089 & 932 & - & 2,834 & 12,855 \\
\hline Bear Stearns & 2,300 & - & - & - & 2,300 \\
\hline Citigroup & 34,106 & 4,053 & 1,319 & 15,904 & 55,382 \\
\hline Goldman Sachs & - & 4,100 & 1,700 & 1,400 & 7,200 \\
\hline JP Morgan Chase & 1,300 & 5,467 & 5,305 & - & 12,072 \\
\hline Lehman Brothers & 200 & 1,300 & 4,100 & 3,400 & 9,000 \\
\hline Merrill Lynch & 26,100 & 2,845 & 12,998 & 13,125 & 55,068 \\
\hline Morgan Stanley & 7,800 & 3,810 & 3,781 & 1,992 & 17,383 \\
\hline \multicolumn{6}{|l|}{ European Banks } \\
\hline Credit Suisse & 3,427 & 3,057 & 530 & 2,523 & 9,357 \\
\hline Deutsche Bank & 2,092 & 5,820 & 3,386 & 3,677 & 14,974 \\
\hline Fortis Bank & 4,359 & 3,660 & 144 & - & 8,163 \\
\hline ING & 565 & - & 8,028 & 25 & 8,617 \\
\hline Royal Bank of Scotland & 3,609 & 1,849 & 2,566 & 4,122 & 12,146 \\
\hline UBS & 21,870 & 348 & 1,716 & 13,871 & 37,805 \\
\hline \multicolumn{6}{|c|}{ Asian and Emerging Market Banks } \\
\hline Aozora Bank & 510.0 & - & - & - & 510.0 \\
\hline Mitsubishi UFJ & 359.5 & 2,348 & 921 & 11 & 3,640 \\
\hline Mizuho & 3,898 & 629 & 2,539 & 584 & 7,650 \\
\hline National Australia Bank & 669.5 & - & - & - & 669.5 \\
\hline Sumitomo Mitsui & 56 & - & - & - & 561.7 \\
\hline \multicolumn{6}{|c|}{ Panel B: Aggregate Crisis-Related Write-Downs (\$ millions) } \\
\hline & ABS CDOs & $\begin{array}{c}\text { Corporate } \\
\text { credit }\end{array}$ & RMBS & Other & Total \\
\hline North American Banks & 84,319 & 23,702 & 42,272 & 59,011 & 209,305 \\
\hline European Banks & 63,464 & 18,579 & 26,423 & 62,634 & 171,100 \\
\hline Asia/Emerging Markets Banks & 9,358 & 4,724 & 5,728 & 3,743 & 23,553 \\
\hline Total & 218,216 & 53,324 & 84,810 & 163,735 & 520,084 \\
\hline
\end{tabular}


Table 10:

Banks Pledgeing Most Asset-Backed Securities (in \$ millions)

\begin{tabular}{|c|c|c|c|}
\hline & Bank & ABS amount & Country \\
\hline 1. & Société Générale & $16,532.0$ & France \\
\hline 2. & Norinchukin Bank & $14,607.9$ & Japan \\
\hline 3. & Dexia & $11,429.7$ & Belgium \\
\hline 4. & Barclays & $9,805.1$ & United Kingdom \\
\hline 5. & UBS & $9,419.0$ & Switzerland \\
\hline 6. & State Street & $9,125.6$ & U.S . \\
\hline 7. & Royal Bank of Scotland & $8,227.8$ & United Kingdom \\
\hline 8. & Bank of Scotland & $6,518.5$ & United Kingdom \\
\hline 9. & U.S. Central Federal Credit Union & $5,293.2$ & U.S . \\
\hline 10. & Bank of Tokyo Mitsubishi & $4,650.5$ & Japan \\
\hline 11. & Depfa Bank & $3,405.0$ & Ireland \\
\hline 12. & Abbey National Treasury & $3,143.3$ & United Kingdom \\
\hline 13. & Bayerische Landesbank & $2,605.4$ & Germany \\
\hline 14. & Deutsche Bank & $2,590.0$ & Germany \\
\hline 15. & Landesbank Baden & $2,505.4$ & Germany \\
\hline 16. & WestLB & $2,096.3$ & United Kingdom \\
\hline 17. & HSH Nordbank & $2,028.8$ & Germany \\
\hline 18. & Calyon & $1,904.7$ & France \\
\hline 19. & Shinkin Central Bank & $1,824.0$ & Japan \\
\hline 20. & DZ Bank & $1,496.5$ & Germany \\
\hline 21. & Skandinaviska Enskilda & $1,444.3$ & Sweden \\
\hline 22. & Dresdner Bank & $1,436.3$ & Germany \\
\hline 23. & PNC Bank & $1,390.9$ & U.S. \\
\hline 24. & Natixis & $1,308.3$ & France \\
\hline 25. & Sumitomo & 959.0 & Japan \\
\hline 26. & Washington Mutual & 920.2 & U.S . \\
\hline 27. & Erste Bank & 884.1 & Austria \\
\hline 28. & Standard Chartered & 869.3 & United Kingdom \\
\hline 29. & Fortis Bank & 838.4 & Belgium \\
\hline 30. & Royal Bank of Canada & 802.0 & Canada \\
\hline 31. & Allied Irish & 770.5 & Ireland \\
\hline 32. & HSBC & 761.0 & United Kingdom \\
\hline 33. & Citibank & 760.8 & U.S \\
\hline 34. & Fifth Third Bank & 736.8 & U.S. \\
\hline 35. & Bank of Montreal & 667.7 & Canada \\
\hline 36. & Commerzbank & 565.0 & Germany \\
\hline 37. & Mizuho & 510.3 & Japan \\
\hline 38. & Metlife & 504.3 & U.S . \\
\hline 39. & Sallie Mae & 503.0 & U.S. \\
\hline 40. & Zions First National Bank & 426.3 & U.S . \\
\hline 41. & RBC Bank & 417.5 & U.S. \\
\hline 42. & Advanta & 236.6 & U.S . \\
\hline 43. & Crédit Industriel et Commercial & 226.3 & France \\
\hline 44. & Ally Bank & 194.8 & U.S . \\
\hline 45. & Mitsubishi UFJ & 192.1 & Japan \\
\hline 46. & First Hawaiian Banks & 155.0 & U.S. \\
\hline 47. & Bank Hapoalim & 149.3 & Israel \\
\hline 48. & California National Bank & 113.0 & U.S . \\
\hline 49. & Norddeutsche Landesbank & $2 b^{2} .2$ & Germany \\
\hline 50. & M\&T Bank & 89.7 & U.S . \\
\hline
\end{tabular}




\section{Figure 1: Facility size (\$ million)}

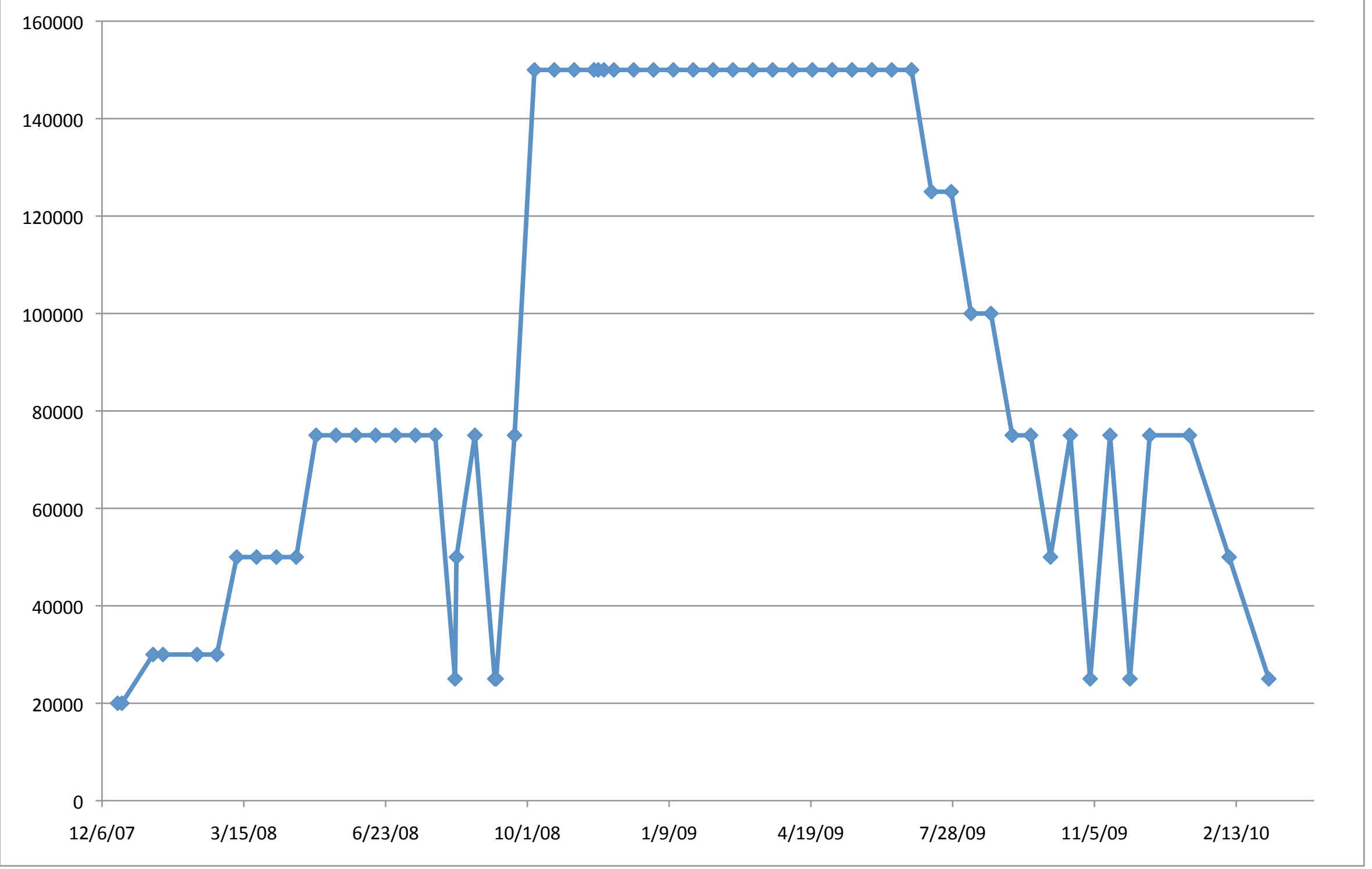




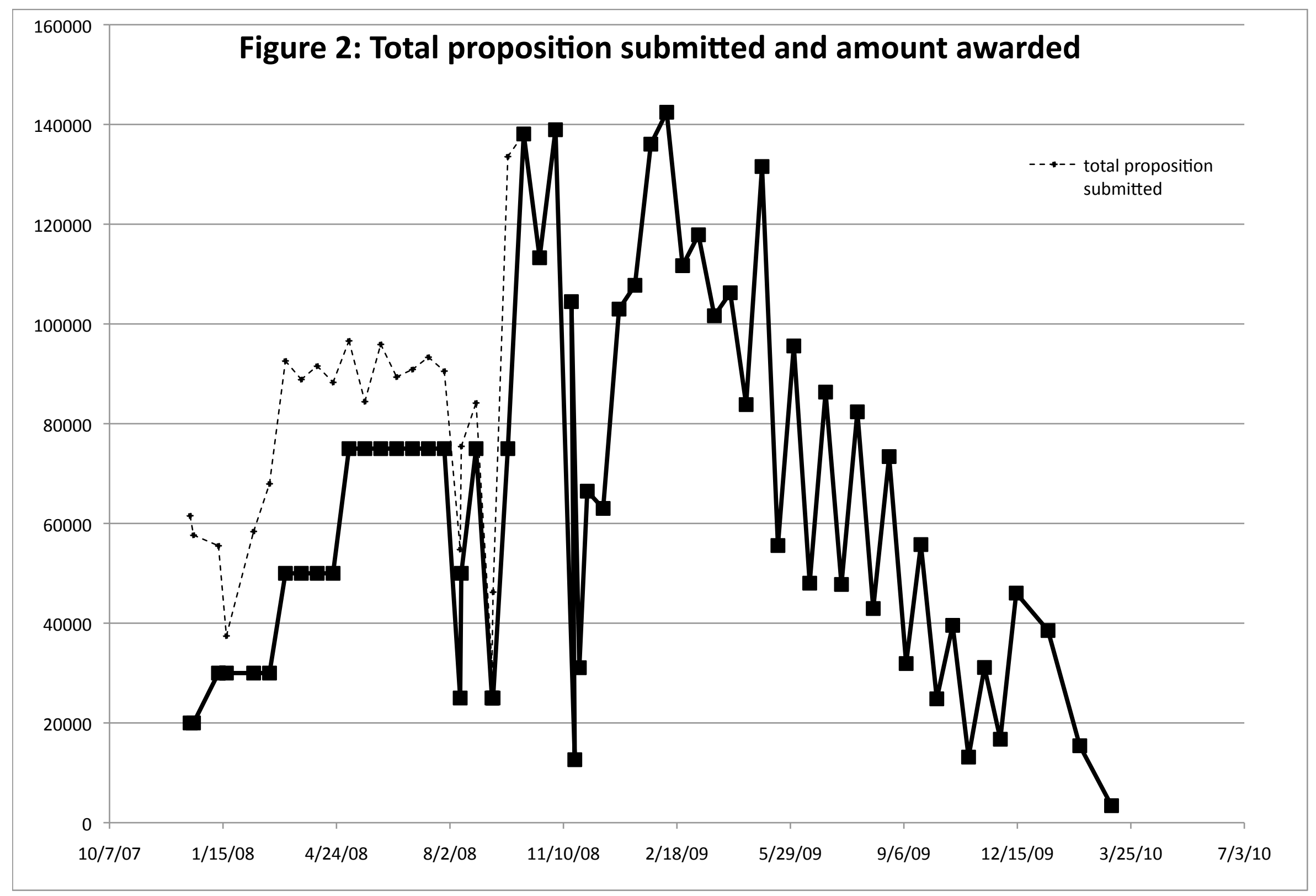


Figure 3: Largest TAF borrowers
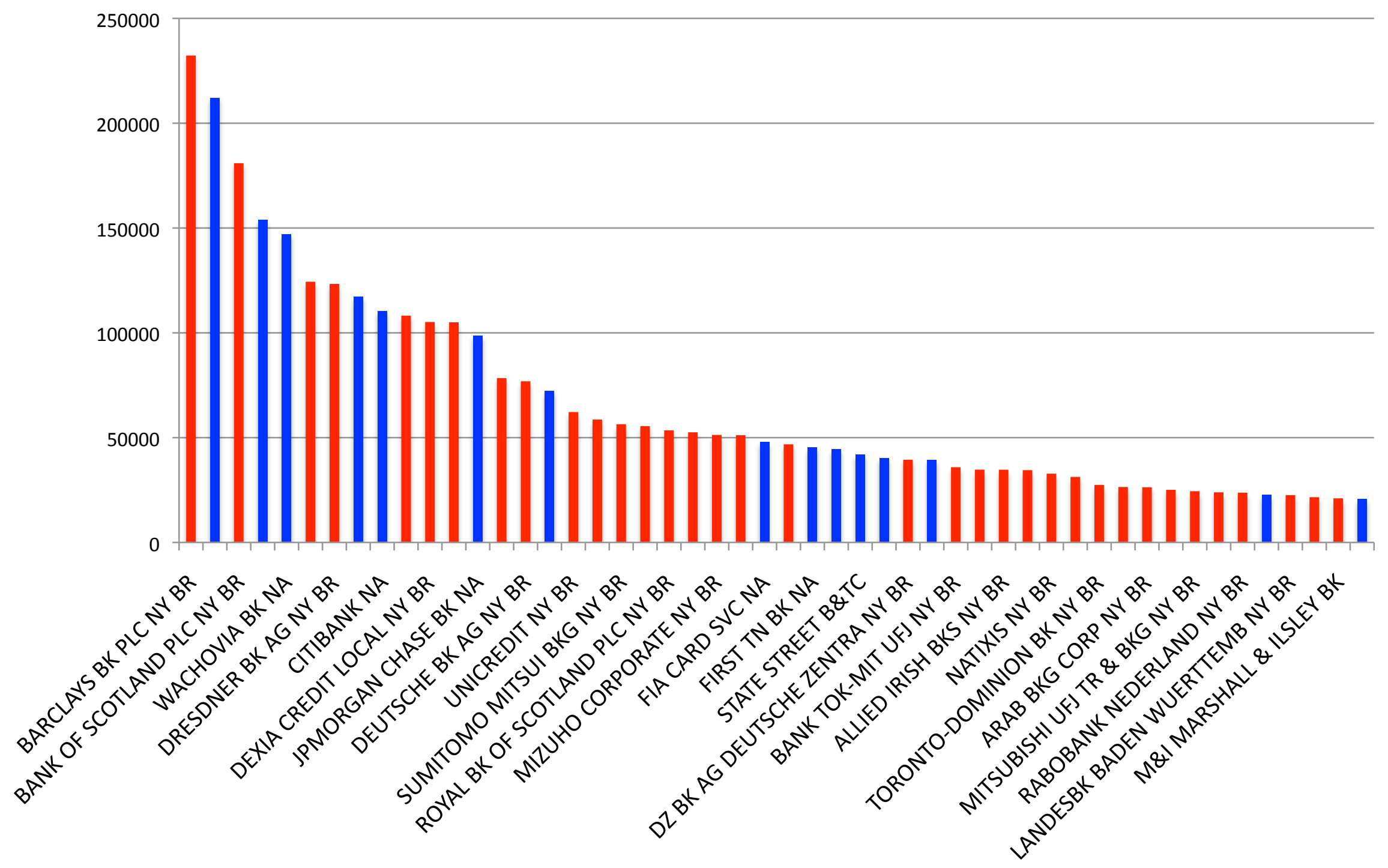